\title{
LOW CARBON URBAN DEVELOPMENT IN SERBIA: CHALLENGES AND OPPORTUNITIES ON THE LOCAL LEVEL ${ }^{*}$
}

\author{
$U D C 711.435: 551.583(497.11)=111$
}

\author{
Milica Bajić Brković, Višnja Sretović, Matija Brković \\ University of Belgrade, Faculty of Architecture, Belgrade, Serbia \\ bajicmb@gmail.com
}

\begin{abstract}
Development of low carbon urban environment stands among the highest priorities countries, cities and regions are faced with. Despite all the efforts, initiatives and concrete actions taken on the international, regional and national level, many countries experience very low or almost insignificant change on a local level. The situation in Serbia resembles these widely recognized dynamics. While on one hand, the responsible ministries and governmental bodies in Serbia have made a visible progress in meeting the challenge of developing low carbon environment over the past decade, it is a fact that actions on a local level aimed at redirecting the current trends and introducing a more responsible development into their cities and towns are very rare and rather sporadically taken. This paper focuses on a local level, and is concerned with the specific challenges and opportunities recognized there. The medium and small towns in Serbia are of primary interest, since their potential for change is least developed and recognized. The paper explores the challenges they deal with, namely, the perceptive, institutional, and legal constraints and goes on to investigate how these constraints could be overcome, or reduced. On the other hand, there are some opportunities that local communities have on hand. The paper takes to the light their strengths, and presents how they could be integrated into the development processes, and employed in order to further empower local communities in making their towns and places more carbon sensitive.
\end{abstract}

Key words: climate change, low carbon urban development, medium and small size towns, Serbia.

\section{INTRODUCTION}

The question of carbon development is of particular interest to professionals worldwide. Until recently, attention was given to carbon emissions, therefore the solutions

Received January 22, 2013

* Acknowledgement: The paper is a result of the research project "Climate Change as a Factor in Spatial Development of Settlements, Natural Scenery and Landscape" (TP36035), Faculty of Architecture, University of Belgrade, funded by the Ministry of Education and Science of the Republic of Serbia, 2011-2014. 
ranged from ways and methods used for improvement of technical and technological performances whose aim is to reduce and neutralize emissions, strict control and responsibility determination, to improvement of regulations. The situation is significantly different today. Carbon emissions are being observed in a wider context, hence the connection to the questions of urban structure, citizens' behavior, lifestyle, etc. In a word, urban development and planning is taken side by side to the question of carbon emissions, and subsequently the problem is being dealt with in a different way.

This paper explores the role and position of small and medium towns in Serbia in that context. The paper is mainly focused on the question of their preparedness to face the challenges of moving toward low carbon development, and capacity they have to undertake independent actions which will lead to the responsive solutions on a local level.

From the low carbon perspective, relevant fields and questions of urban development refer to:

1. Land allocation to different use and intensity of its use

2. Activities in urban areas

3. Urban structure and the corresponding urban development standards

4. Techniques of building

5. Traffic and transportation

6. Climate-responsible planning and building

7. Relationship between built and non-built environment

8. Existence and proportion of green and open spaces within city boundaries

9. Building materials

10. Technical and technological standards and equipment

Measures taken on the local level within each category are of multiple importance. Their effects could be observed not only within local community, but also within the entire region, even whole country. Although the individual effects may be small, when taken together or in multiple combination, they generate positive community-level impacts. This is especially relevant in the case of Serbia, due to the specifics of its settlements network and the level of urbanization.

The potential for change of the Serbian medium and small towns is least recognized. They often lack genuine initiatives which need to be taken from within. This paper explores the challenges they deal with, and goes on to investigate how these constraints could be overcome, or reduced. On the opposite side, there are the opportunities these local communities have on hand. The paper takes to the light their strengths, and presents how they could be integrated into the development processes, and employed in order to further empower them in making their towns and places more carbon responsive.

\section{REASONS FOR ADDRESSING LOW CARBON DEVELOPMENT ON THE LOCAL LEVEL}

It is commonly accepted in Serbia that coping with issues related to low-carbon is a state responsibility. It is up to the state to develop national or regional strategies and regulations, in which way a workable framework for actions as well as instructions for the local level actions will be provided. Being at the very end of the process makes local level entirely reliant on the top-down hierarchical order, and virtually with no effective power for independent actions. However, the experience of many cities and towns speaks differently, one can act upon making cities and towns more low carbon responsive from differ- 
ent levels of responsibilities. The stand currently present in Serbia is based on a traditional development and planning hierarchy paradigm, but is far from reality and real potentials local communities actually have. It is actually here, at the local level, that multiple possibilities exist. As in many other spheres of urban development, local initiative is of great importance here and can contribute greatly to facing the challenge successfully. Local level is actually a key level because,

1. It is the place where many changes are taking place, affecting the increase in carbon emissions;

2. Numerous effects of negative changes can be felt only on the local level;

3. Those responsible for production of carbon emissions i.e. those who need to change their behavior and eliminate the causes, are the easiest to be recognized at this level;

4. For some changes and processes control is being established and progress monitored on the local level;

5. All relevant stakeholders and actors are present here, so partnerships are easiest to be set up and realized;

6. Local level will easily get the citizens' support in a sense that everyone will have its role and could participate.

Constructive relation to dealing with the problem of climate changes and development of low carbon environment means parallel and integrated actions on many different levels. On the international level, one can speak about developing conventions, international agreements and cooperation, or about developing directives, changes and amendments to legislations, etc. Countries are individually developing national strategies, defining policies, establishing rules, modifying legislations, introducing different measures, defining responsibilities and sanctions. Depending on the institutional organization, but also geographic, economic and social characteristics, the problem is often being approached and dealt with on a regional level, especially in the areas with activities which are affecting climate change or which are, for some other reason, seen as national responsibility. National responsibility also includes different sectorial approaches, meaning that within particular sectors is this question being dealt with, and appropriate measures and actions taken.

Local level, on the other hand, may have a crucial role, and the understanding of its own role inspires local communities to develop and take measures and actions, as well as contribute positively to the climate change reduction. In doing so, it is not only that local governments hold the responsibility. Important agents are also different local formal and informal associations, non-governmental organizations, local manufacturers, industries, or any other organizations and associations in local surroundings.

\section{SEARCHING FOR BETTER: OPPORTUNITIES AND POTENTIALS}

As far as medium and small cities are concerned, a recent research done for the execution of the Spatial Development Plan of Serbia, has shown that the country has the urban network and urban capacity which can support a successful move to the low-carbon urban development. The advantages are recognized as:

\footnotetext{
${ }^{1}$ Taken and adapted from: Bajić Brković, M. (2010): "Ka održivom razvoju gradova u Srbiji", in Bajić Brković, M. ed. (2010): Kreativne strategije za održivi razvoj gradova u Srbiji. Arhitektonski fakultet Univerziteta u Beogradu, ISBN 978-86-7924-035-4, p. 24-25.
} 
1. Relatively good spatial network/arrangement of the settlements, i.e. the urbanization matrix on the country's territory;

2. Emerging polycentric model of spatial organization and development ${ }^{2}$ within the regional entities, or the corresponding urban clusters;

3. Tendencies for forming urban clusters in the areas where they have not been developed yet, within which functional specializations, diversification of activities, as well as complementarities between towns and other settlements within the clusters will bear the crucial role in the future;

4. As for the individual settlements, a multifunctional urban matrix without strict zoning, as a rewarding basis for planning/building of low-carbon environment;

5. Internal spatial capacity for new developments or renewal of the existing ones, on brownfield locations, new sites in the urban fringe areas, singular infill, etc.;

6. Relatively lower spatial carbon emissions per land/spatial unit or per capita;

7. Growing interest and support of non-governmental sector for new initiatives and new projects in the area of quality of life, eco-development, energy, etc.;

8. Development of cross-border cooperation, especially cooperation with the EU cities which strongly support low carbon urban development.

Detailed analysis has revealed that there are some very specific spatial and functional opportunities on a local level which support low carbon development of these settlements. What also gives support to this is Serbia's Energy Development Strategy, a number of individual projects and initiatives undertaken so far, as well as newer tendencies of giving more power to local governments, widening the scope of their responsibilities and strengthening their financial capacity by redistribution and restructuring of the national budget.

\section{COMPREHENSIVE CONCEPTS VS. PRACTICAL GUIDELINES}

Local initiatives can emerge:

1. As comprehensive initiatives: strategies, plans and projects, and/or

2. As pragmatic guidelines, as part of urban development regulation specifically designed to be implemented on a local level.

\subsection{Comprehensive Concepts}

In Serbian regulation, it is on General Urban Plan (GUP) or Plan of General Regulation (RP) to take account of urban development as a whole, and address urban development issues in a comprehensive way. Among others, they address questions which may embrace those that are relevant from the point of view of adjusting to the low carbon future. These include: (1) designing solutions according to the corresponding parameters such as urban development density, floor area ratio, percentage of land occupancy, vertical and horizontal regulations, etc.; (2) transportation mode and road network (3) relation between built and non-built areas; (4) scheming open spaces in terms of their spatial dis-

\footnotetext{
${ }^{2}$ This paper deals with medium and small cities, hence the urban matrix is observed on the regional or mezzo level. It excludes Belgrade, as dominant throughout the country, as well as regional centers such as Nis, Kragujevac and Novi Sad.
} 
tribution and types; (5) securing and protecting green and open air spaces, or non-developed spaces in natural surroundings; and (6) designing building standards in response to local needs, potentials and constraints. However, it seems that a huge potential these plans have within their corresponding responsibilities have not been recognized yet, and a lack of expected results in practice therefore is not surprising.

In general, the segment on building standards and guidelines represent the most important part of every comprehensive plan. It is there where one can see to what extent is the matter of low-carbon environment mastered in particular area or place. It is also there that one can recognize the capacity of planning to fulfill the demands of the low carbon urban environment. Regrettably, this is a point which has been given the least attention in Serbia so far.

Even though, there are some positive moves. The Serbian legislation recognizes and regulates the questions of energy efficiency, environmental protection and other potentially influential subjects, which appear important for creating and sustaining urban carbon development.

\subsection{Practical Guidelines}

It is often thought that developing the guidelines is only a segment within the General Urban Plan, or the Plan of Detailed Regulation. What we have in mind here, however, is the local regulation which can be independently developed and implemented by any local community. The advantage of doing so is seen in its inherent capacity to: (1) deal with details; (2) be adjusted solely to local conditions; (3) easily adjust to local conditions and changes; (4) be result of participation of all interested or relevant agents; (5) support local community and local values, and (6) respond, i.e. secure solutions for the concrete problems and questions specific for the area, and status quo of a place. ${ }^{3}$.

What can local communities immediately change and implement in their cities and towns in Serbia?

1. Place the development of low carbon environment on the forefront of public interest;

2. Set immediate and concrete goals of developing low-carbon environment in their community;

3. Make these goals operational for each sector, and define responsibilities for each particular stakeholder or participant;

4. Design the Practical Guidelines to be implemented in different sectors of urban development, and emphasize the role of physical development;

5. Define the low carbon principles of land use responsive to local specifics and needs, and design the building standards accordingly;

6. Set the rules of the low-carbon behavior for different sectors: energy, carbon emissions etc.

7. Cooperate with investors and builders, as well as with all others connected to urban development and building;

8. Strengthen citizens' awareness and support their initiatives;

9. Develop programs to influence a change of life style;

10. Develop partnership with all who work towards urban sustainability: start educational programs and, especially, cooperate with NGOs and schools.

\footnotetext{
${ }^{3}$ There are many good examples and practices, like for instance, Malme (Sweden), Perth (Australia), Sarriguren (Spain), Porto (Portugal), Cambridge (UK), etc.
} 
All of these could be developed independently from the state strategies and regulations, and could be implemented by any local community.

\section{Challenges AT THE LOCAL LEVEL}

Although there are no formal barriers for carrying out low carbon planning and development practice in Serbia, in practice, no significant changes has been observed so far. The planning and development model, whose roots are deeply anchored in traditional understanding or urban functions, structure and form, discloses how strong the inherited practice is, where only some minor innovations towards general requirements of sustainability have taken place so far. A survey recently undertaken as part of the project conducted at the Faculty of Architecture, University of Belgrade ${ }^{4}$, has revealed presence of different obstacles in making a major transition, which roughly can be identified as: (1) obstacles in perception or in behavior, (2) institutional obstacles, and (3) economic obstacles.

\subsection{Obstacles in perception or behavior}

One of the biggest obstacles is a lack of understanding of the real meaning and importance of carbon emissions, the influence they have on climate change, quality of life in cities, and how the concept of low carbon is related to urban development. It is being followed by insufficient understanding of ways and possibilities, already available, to affect reduction of carbon emissions, and the role urban planners and designers have in dealing with it. Typically, the problem of carbon emissions is most often related to traffic and transportation, while other relations are being overlooked or simplified, like its relevance to urban matrix, lot coverage density, land uses, location of certain urban functions, relationship between built and non-built space, lack of green areas, etc. What certainly contributes to such perception and understanding is a great complexity of the question and a lack of relevant information. Often, the key point is insufficient professional capacity to deal with this complex problem.

On the other hand, the difference in perception of what are the important issues to be dealt with on a local level, what are local priorities, or which issues are recognized as key development questions, very often are far away from the issue of climate change or carbon emission, regardless of their importance and presence. This normally occurs in the communities that are hampered by serious and significant development problems. This is very much present in Serbia, especially in small cities and towns which, faced with many existential or economic challenges, simply do not place the question of carbon emissions high on the list of their priorities. When compared to urgent issues which need to be solved immediately, such as providing employment opportunities, or giving a boost to economic development, the benefits of dealing with the issue of climate change are either not recognized or are underestimated.

There is also inertia in perception of urban space and urban development. The majority of our experts still holds on to functionalist theories and the paradigms dominant in the 70 s or 80 s, contrary to what one can see in other places due to a new thinking that Postmoderna brought into the profession.

${ }^{4}$ Ref. ad 1 
There is also a gap present between verbal or generally expressed interest in different actions, and readiness to actually act and support the change.

In coping with these obstacles, it is particularly important to raise the awareness of all those who are responsible for urban development, be that the state, local governments and local bodies, NGOs, different stakeholders, etc. Much attention should be given to the public, because involving citizens in what is a domain of genuine public interest is often critical. Raising public awareness and emphasizing the role and importance of citizens' involvement should be kept in continuity along the whole process. The relationship between carbon emissions and urban development, represents a typical urban planning concern where the win-win situation will be achieved only when all concerned will become involved. The inert behavior and thinking present in Serbia place too much focus on the role of state, by assigning the state as the only one to raise the question, develop strategies, set the regulations and only then, through scale of responsibilities, bring it down to a local level. On the contrary, this issue needs to be addressed on more than one level in order to produce the real results and success. There are many examples of local communities worldwide showing the strength and potential local level has, where actions were started and solutions implemented from "down-up", by the genuine grass roots initiatives.

\subsection{Institutional obstacles}

Some of the researches conducted in the countries of South-East Europe5 clearly illustrate that the institutional arrangements and the way institutions operate, often present the main reason why changes in certain domains of urban development and management are either slow or are not taking place at all. From the perspective of what is relevant for the problem we are here exploring, these seem to be the key factors ${ }^{6}$ :

1. Poor connections or inappropriate coordination between different sectors and levels of management;

2. Lack of appropriate information and data, or non existent system for communication of information and data;

3. Lack of adequate local policies and regulations;

4. Limited jurisdiction of local governments;

5. Asymmetric division of power and resources in relevant institutions and bodies or within community;

6. Insufficient or inadequate competences in decision-making bodies;

7. Lack of public support, or uninformed public;

8. Opportunism in decision-making;

9. Unawareness or poor awareness of public interest;

Institutional, perceptive and obstacles in behavior are deeply interconnected. It is not possible to address one without tackling the other. Individual and sporadic actions undertaken so far have not produced an impetus for change in reality, mostly due to the particularized nature of these actions. As stated above, the kind of challenge the country is faced with when dealing with carbon emissions, requires an effort to bring together all

\footnotetext{
${ }^{5}$ REC: http:// www.rec.org

${ }^{6}$ Look at: Bajić Brković, Milica (2009): Prostorni razvoj i uređenje gradova i ostalih urbanih naselja u Srbiji. Tematska sveska, PPRS, Arhitektonski fakulktet i Republička agencija za prostorno planiranje, Beograd.
} 
those who have a role, have interest for the matter, or can contribute in making it happen. At the local level it is even more important to handle the matter in such a way. Including citizens and local partners is the only way to provide a basis for a win-win result. Today, we are witnessing rare citizens' initiatives, while the roles of other agents - NGO's, professional and interest associations etc, are sporadic and often unrecognized as relevant for the problem.

\subsection{Economic obstacles}

Every shift to different model of behavior in space and spatial development management, or starting projects such as those referring to low-carbon development, require substantial financial support. In that respect, Serbia certainly is not among the countries able to make an easy transition to the carbon responsive urban planning and development. As the key obstacles we recognize the following:

1. The cost/expenditure estimation of a shift, and the availability to provide necessary funds;

2. The existing funds are already allocated to other objectives and projects, or are planned to be allocated to other projects;

3. Local governments are financially weak, and have no sufficient funds within their budgets to meet the ends required by a shift;

4. Benefits from low carbon development are diffusive and not visible in immediate future, whereas the investments are most often concentrated on certain groups or aspects of development; these make the matter les attractive for financial support, and less appealing in decision making.

Notwithstanding the above, it should be stressed that the real issue here is more often a question of behavior and perception, and the way of looking at things, than it is case of real inabilities of local governments to initiate a change ${ }^{7}$. There are many examples of European cities and towns where local governments have been successful in redirecting the trends, and turning their places to low carbon development solely by their own initiatives, and providing financial support by emphasizing the merits these changes will generate, instead of focusing the cost and expenditure, as is the case in Serbia. There is a growing awareness worldwide that delaying the problem solving to some future action is likely to increase the cost associated with its resolution, and that today's actions in fact work on account of saving future funds and making future expenditures more accountable.

\section{OVERCOMING THE OBSTACLES}

Overcoming the obstacles can be performed on different levels. It would be unreal and misleading to expect or believe that the shortcomings and problems associated with obstacles could and would be solved solely by the state, and that it has to be done hierarchically, from the higher to the lower levels of management. In the process of their over-

\footnotetext{
${ }^{7}$ Look at: ISOCARP (2011): Liveable Cities: Urbanizing World-Meeting the Challenge, 47th ISOCARP Congress, Wuhan, PR China, Congress Introductions and Papers; ISOCARP (2009): Low Carbon Cities, 45 th ISOCARP Congress, Porto, Portugal, Congress Introductions and Papers.
} 
coming, every level has its own field of operation. There is a wide range of possibilities available on a local level:

1. Promoting the concept of "investing in future" instead of emphasizing the cost;

2. Defining clear priorities for the short and medium term, and focus the advantages of low carbon development;

3. Giving a lead to programs and actions whose effect can be seen immediately and prioritizing those who provide choices;

4. In programs and actions, emphasizing the relation: low carbon development-environment-economy-society;

5. Undertaking actions in a sustainable way and highlighting their benefits;

6. Expanding a framework within which social expenses and social benefits are taken into account in a sustainable way, instead of merely relying on conventional economic cost-benefit approach;

7. Stimulating and supporting energy rational and eco-sensitive production instead of energy intensive modes;

8. Including public and working on raising their awareness regarding the importance of building low carbon environment, and the role they may play within the process;

9. Developing city-to-city and town-to-town cooperation and implementing both vertical and horizontal coordination in managing public affairs;

10. Learning from others, and exploring the best practices.

\section{CONCLUDING REMARKS}

Although Serbia is not yet fully ready for a change and switch to the low-carbon development model, some important initial steps have already been made. Local governments have gained jurisdiction over a range of questions in connection to this subject matter and have a power to, within their authority, contribute to these sustainable solutions. Nevertheless, a significant discrepancy between state actions on the one hand, and reality on a local level on the other, is visible and enlarging. The importance of low carbon development is not yet fully recognized on a local level. In majority of small and middle sized cities and towns in Serbia the issue of making their environments more ecosensitive and eco-friendly has not been acknowledged yet, nor has the importance of switching to the planning and development paradigm which will make their places healthier and more comfortable for living yet been raised. All of them are awaiting for governmental strategies and actions, deeply committed to the old practice of having the state to initiate a change.

This paper advocates a different approach. Having in mind the complexity of the question, the authors call for differentiation of responsibilities, and activation of the real power and competencies local governments have in dealing with this matter. Their argument is being supported at least by the following:

1. Many actions and projects can be started and completed on a local level, even if there is no state strategy or worked-out measures on the higher levels of management;

2. Being proactive, developing partnership and including all the relevant agents are the important preconditions in dealing with the issue of developing the low carbon environment; all of these could be started and realized by local initiatives; 
3. At the local level it is the easiest to "attack" a problem and start working on it; it is the exact place where every problem associated with carbon emission occurs in the first place, and where it is easiest to detect it; often, even to cope with it;

4. Local level is a place where changes usually are felt first, including the benefits from the switch to the carbon responsive development;

For making positive moves toward the low carbon development at the local level, local governments have to change their local regulations, take actions, raise the awareness about importance of this question, and support those projects and initiatives which can serve as "leading and good examples".

\section{REFERENCES}

1. Bajić Brković, M., "Liveable Cities: Urbanizing World", Introduction to the 47th ISOCARP Congress, Liveable Cities: Urbanizing World - Meeting the Challenge, Congress Introduction and Papers, Wuhan, PR China, pp. 7-17, ISBN 978-94-90354-12-1, October 2011.

2. Bajić Brković, M., "Ka održivom razvoju gradova u Srbiji", u Bajić Brković, M., urednik, Kreativne strategije za održivi razvoj gradova u Srbiji. Arhitektonski fakultet Univerziteta u Beogradu, ISBN 97886-7924-035-4, 2010.

3. Bajić Brković, Milica, Prostorni razvoj i uređenje gradova i ostalih urbanih naselja u Srbiji. Tematska sveska, PPRS, Arhitektonski fakultet i Republička agencija za prostorno planiranje, Beograd, 2009.

4. Bajić Brković, M., B. Mitrović, "Informatičko-komunikaciona infrastruktura kao podrška planiranju u Srbiji: stanje i perspektive", u: Grupa autora, Prostorni razvoj magistralnih koridora, IAUS, Posebna izdanja 41, ISBN 86-80329-36-3, 2003.

5. Brković, Matija, Višnja Sretović, Marija Cvetinović, "Green Energy to Support Lievability: A Case Study of Energy Shift to the Small Hydro-Systems in Serbia", 47th ISOCARP Congress, Congress Introductions and Papers, Wuhan, PR China, ISBN 978-94-90354-12-1, October 2011.

6. EU Council of Ministers for Urban Development and Territorial Cohesion (UTDC), (2007b): "The Leipzig Charter on sustainable European Cities", available at:

http://www.eu2007.de/en/news/download_docs/mai/0524/AN/075DokumentLeipzigCharta.pdf.

7. Gossip, C., Shi Nan, eds., Liveable Cities:Urbanizing World. ISOCARP REVIEW 07. ISOCARP, The Hague, The Netherlands, ISBN 978-94-90354-00-8 (ISOCARP), 978-0-415-50956-5 (Routlidge), 2011.

8. Gossip, C., F. Brandao Alves, eds., Low Carbon Cities, ISOCARP Review 05, The Hague, The Netherlands, ISBN 978-94-90354-04-6, 2009.

9. Handely, J. Carter J., Adaptation Strategies for the Climate Change in the Urban Environment. ASCCUE report to the National Steering Group, Manchaster: Center for urban and regional ecologz, School for Environment and development, Universitz of Manchaster, UK, 2006.

10. Prairies, Y. T., J. J. Cole, "Carbon, Unifying Currency", in: Gene E. Likens, ed., Encyclopidia of Inland Waters, Vol. 2, pp. 743-746, Oxford. UK, 2009.

11. Smith, G., J. Scott, Living Cities: An Urban Mzth? Government and Sustainability in Australia, Rosenberg Press, Dural, Au. ISBN 1-877058-43-2, 2006.

12. Sretović, Višnja, Matija Brković, Marija Cvetinović, "Green Energy and Cultural Heritage Preservation: Case Studies from Serbia", 47th ISOCARP Congress, Congress Introductions and Papers, Wuhan, PR China, ISBN 978-94-90354-12-1, October 2011. 


\section{KARBON ODGOVORAN URBANI RAZVOJ U SRBIJI: IZAZOVI I MOGUĆNOSTI NA LOKALNOM NIVOU}

\section{Milica Bajić Brković, Višnja Sretović, Matija Brković}

Razvoj karbon odgovornih gradova je jedan od prioriteta u zemljama, gradovima i regionima sveta. Uprkos mnogim naporima, inicijativama i konkretnim akcijama, koji se preduzimaju na međunarodnom, regionalnim ili nacionalnim nivoima, u mnogim sredinama promene su male ili izostaju u potpunosti. Situacija u Srbiji je slična. Dok sa jedne strane, odgovarajuća ministarstva $i$ nacionalna tela čine napore u pravcu približavanja međunarodno zacrtanom cilju, na lokalnom nivou inicijative su retke i sporadične. Ovaj prilog afirmiše značaj lokalnog nivoa i obrađuje specifična pitanja-izazove i mogućnosti koji se u lokalnim zajednicama sreću. Gradovi srednje veličine i mali gradovi su od primarnog interesa ovde jer je njihov potencijal za promene najmanje razvijen i često nije na zadovoljavajući način prepoznat. U tekstu se raspravlja o izazovima sa kojima se ta urbana naselja suočavaju-perceptivnim, institucionalnim $i$ zakonodavnim preprekama, i iznose mogućnosti za njihovo prevazilaženje. Takođe, ovde se ukazuje na potencijal koji postoji u ovim zajednicama i predlažu mere za njegovo aktiviranje kako bi lokalne zajednice svoj razvoj usmerile ka karbon odgovornom urbanom okruženju.

Ključne reči: klimatske promene, karbon odgovoran urbani razvoj, mali i srednji gradovi, Srbija. 